The rural university campus and support for rural innovation

David Charles*

* Deputy head of school and professor of innovation and strategic management Lincoln Business School,

University of Lincoln,

Brayford Pool,

Lincoln, LN6 7TS

dcharles@lincoln.ac.uk 


\section{Abstract}

This paper examines the potential for engagement in local innovation activities of six rural university campus developments in the UK. A number of common narratives emerged around the tension between local educational interests, and the needs of local industry. The paper examines both the strategies of the campuses and the expectations of local partners. Whilst these new campuses have been able to add to the regional innovation systems of rural areas, they struggle with economies of scale and scope. Where disciplinary specialisation has been pursued, potential exists for engagement with niche clusters, although a long development period is required. Where campuses have focused on broad educational equity issues, engagement with business has been difficult to achieve. Overall policies to enhance rural innovation through new university campuses must be seen to be very long term strategies and not necessarily congruent with strategies to increase $\mathrm{HE}$ participation and equity of opportunity. 


\section{Introduction}

Much of the research on university contribution to regional innovation, at least in the UK and other large countries, focuses on larger metropolitan based universities, often those that are research intensive. Emphasis is placed on excellent universities located in relatively well endowed regions, in which regional innovation systems are well developed (see for example Youtie and Shapira, 2008). Regions that are mainly rural in nature, often highly peripheral and with very limited university provision, perhaps in the form of a small university in the main town, or even just in the form of a small satellite campus to a university based in a city are rarely the subject of study (see Allison and Eversole (2008) for an exception). Yet these small university campuses are the subject of keen political interest in their regions, as local interests lobby hard for university investment in order to support their local economies. The difficulties are great however and such campuses are subject to wide-ranging demands from a small asset base (Charles, 2009). This paper examines the experience of campuses in six rural locations in Scotland and the North of England ${ }^{1}$, with a particular focus on the contributions they are able to make to local innovation capacities. The main research question is in what way can small university campuses in rural areas meet the demands and expectations of their regions.

The six case studies focus on universities or university campuses which emerged in the last twenty years, although by varying processes. Three involve new universities, each evolving from a different set of precursor institutions, whilst the other three are satellite campuses either acquired or newly established by urban-based universities. All were underpinned by a strong local desire to see a university presence in the area, but whilst there are some parallels each is also distinctive.

A number of common or shared narratives emerged from these case studies. Central to this was the tension between meeting local educational interests which tended to be generic, and the development of areas of research specialisation linked with local industry. The relatively small scale of institutions meant that it was difficult to adopt both strategies at the same time, so the campuses were almost bound to fail to meet expectations on either education or collaboration with local industry, and in some cases on both. Local partners had started to be more realistic on expectations, especially when in several cases there was a threat of complete closure which occurred on four of the sites.

The limitations of the campuses meant that business links tended to be in relatively narrow niches, although the needs of these rural areas were quite diverse, in most cases with relatively high proportions of manufacturing activity, and certainly much higher than the large cities where most university research is based. Despite the presence of new universities in the regions, partners were still looking to universities elsewhere to meet the needs of local small and medium-sized enterprises (SMEs), even whilst trying to build the capacity of the new rural campuses.

The next section examines the existing literature relating to university local engagement and university branch campuses, especially those based in more rural areas. Rural areas are acknowledged to have particular development needs and hence the demands placed on rural

\footnotetext{
${ }^{1}$ The author was based in Scotland at the University of Strathclyde when the research was undertaken, hence the selection of cases in Scotland and the North of England. He subsequently moved to Lincoln after the collection of data.
} 
campuses have a particular character. The evolution of rural university campuses in the UK is then outlined briefly to provide a context for the case studies which are then described in more detail along with the method. The local context of each campus is important for understanding the potential role and this is provided in a short section which particularly notes the above average level of manufacturing employment in the regions.

The analysis section of the paper examines the scale and level of specialisation of campuses and how they have addressed the dilemma between disciplinary specialisation and a broader focus on meeting educational equity demands. This is then followed by discussion of community expectations, support for business innovation and the viability of campuses, before drawing some final conclusions and policy implications.

\section{University local engagement and branch campuses}

The literature on universities and regional innovation typically draws upon some form of regional or local innovation system perspective, in which the university is a source of knowledge or resources which constitutes a significant actor within an innovation system (Uyarra, 2010). The scale and complexity of a university is such that it often performs a number of different roles within its innovation system, as a source of human capital, as a source of specialist knowledge, an incubator of firms perhaps, as a creator of social capital and potentially many other roles (Charles, 2006). Urban regions also often have several universities, with perhaps some specialised on particular roles or sectors, and each adding to the thickness of the institutional capacity (Goddard and Vallance, 2013). Successful regions also typically exhibit some form of agglomeration and hence specialisation, which perhaps co-evolves with the areas of specialisation of the universities (Patton and Kenney, 2010). So even looking beyond the much cited examples from California and Massachusetts, there are regions with specialist clusters where the university has closely related specialisations - oil and gas in Aberdeen, or materials in Sheffield for example (Witty, 2013).

In more rural regions though the challenge for universities and for regional innovation policy is much greater, with usually a more diverse and diffuse economic base, a predominance of small and microbusinesses, and with weak knowledge institutions, often with an absence of universities. In response, in more recent years there has been active lobbying by rural regions for a university presence, and with some investment in new campuses and universities. The UK has seen a number of such developments (DIUS, 2008), as have other countries in Europe and beyond (UNICREDS, 2012). Australia for example has seen a long term desire by rural towns to attract university campuses (Garlick; 1998: Charles et al, 2006) with similar trends in Canada and Norway (Pineiro et al 2016 forthcoming). Governments have also looked to increase HE provision in rural areas or 'cold spots' where an 'absence of tertiary provision' acts as a 'brake on local growth' (Willetts, 2014). Often the rationale is the same: regions want a university to help retain young talented people, to provide local study opportunities and to support local business and the wider community (Charles et al 2006). Rarely do such regions gain a large full-range university, sometimes an existing small college might become part of a university based elsewhere, a few new small universities have been established, or perhaps a new satellite campus is set up. The extent to which such developments have successfully supported local innovation systems has not yet been fully assessed, although a new study by Wise (2016) suggests that regional universities in Australia do seek to support local innovation through specialisation in research that matches local needs. 
Rural universities and campuses must be seen, even more than other universities, within the context of theories of the engaged university (Chatterton and Goddard, 2000; Gunasekara, 2006, Uyarra, 2010). The engaged university recognises that the nature of linkages between the university and the community are diverse and multi-sectoral, cover teaching, research and service roles, and are interactive, responsive involving forms of collaborative governance (Uyarra, 2010). More narrowly defined theories relating to the commercialisation of university technologies (Siegel at al 2007) are ex ante less likely to apply to the rural university campus due to the small scale and low research intensity of the campus coupled with the characteristics of the surrounding rural economy in which firms are typically less technologically oriented than in the cities.

Much of the engaged university literature refers also to the 'civic' role with an implicit connection to the city (Bender, 1991; Goddard and Vallance, 2013), but with a more important and explicit notion that the mission of the university includes a local dimension rather than purely a national or even international focus (Uyarra, 2010). Funding sources are an important driver in this role (OECD, 2007), although not the only rationale, as individuals as well as organisational missions focus on engagement for a variety of reasons (Benneworth, 2013).

The significance of the role of universities in or on rural areas also draws on particular understanding of the nature of rural development, as neo-endogenous (Atterton and Thompson, 2010), in which local partnerships seek to develop embedded initiatives but drawing on a mix of both internal and external resources. In this, universities are seen as key institutions for their ability to link external knowledge and research links, and inward flows of students, with local actors and initiatives. The combination of global knowledge connections and processes of local co-production and exchange of knowledge, offer greater potential for rural innovation and development than reliance on purely external or purely internal knowledge processes alone. Thus the university is not simply a source of external knowledge to be applied within the region, but builds new combinations of knowledge in co-production with local actors to meet the specific and unique needs of the region (Atterton and Thompson, 2010; Ward et al 2005). The nature of these combinations and the effect on path development (Isaksen and Trippl, 2014) in the region will however depend on the resources available within the university and the investment opportunities in the region. Path extension would occur if the university supported incremental development of local industries, and is probably the most likely outcome. However, path renewal from the switching of local firms to new product areas, and path creation from the start-up of new industries could arise if the university was engaged in substantial research and enterprise activity.

The characterisation of the rural university campus as an engaged campus would logically appear to draw on three conditions, which invariably form part of the genesis story of the campus. There first needs to be some form of demand from the local community for a university presence, usually driven by consideration of equity of access to higher education or an expectation that the university will contribute to the local economy (see for example in Hills and Lingard, 2003; Karlsen, 2005). The new university, or the parent university of a new campus, makes a decision to locate in a rural area, knowing the local demands, and with a mission to engage with the community and those demands (Garlick, 1998). A university without such a mission would usually opt for an urban location where access to a supply of students and staff is easier. For the branch campus, the parent university has usually formed a strategic intent to locate in a rural area either to take on an existing campus with a rural mission or because they are convinced there is a worthwhile new market as identified through 
local demand. And finally, there needs to be a political will to support engaged rural university campuses with investment by national and/or local partners in the new campus and in the revenues associated with additional student places (Arbo and Eskelinen, 2003).

The precise form of the rural campus varies between national systems of higher education. The very term branch campus has different connotations, even leaving aside those international campuses aimed at accessing new lucrative student markets. In the US the rural branch campus is likely to be an independent campus within a state university system, usually in the form of a community college (Schuman, 2009). So a state university system may have a mixture of one or two research universities and a range of other campuses of which some are smaller and located in more rural locations, but with a more restricted curriculum. This differs greatly from the UK where a rural branch campus is an integral part of an independent university based elsewhere, or where a rural university is a fully independent university without the supervision of a wider state system.

There is a more comparable model and a richer literature on rural branch campuses in Australia where the governance and spatial form of universities is more similar to the UK, and where a high proportion of universities have some form of rural campus, often with several such campuses within the same institution (Garlick, 1998). Here, 'regional' or non-metropolitan, university campuses have been used as a form of regional development policy (Allison and Eversole, 2008), with the recognition that they could be used as 'social and economic engines' (Dudley and Longley, 2004, 72).

Elsewhere in Europe, new universities have been established in rural areas, sometimes even in island archipelagos, but usually with limited research capacity (Charles, 2006). Many countries have sought to expand $\mathrm{HE}$ provision, usually through the addition of new universities, and in the process a number of these have been established in regions lacking a major urban focus - in some countries all regions are felt to need a university, even if largely rural, hence the University of the Aegean, Greece or University of Tromso, Norway (Pinheiro, 2014). Various models of institution have been developed other than standard universities, using various forms of networked model and satellite campuses, although invariably with a primary focus on the creation of educational opportunities rather than research and innovation.

Some countries have opted for polytechnics, or universities of applied sciences in rural areas rather than universities (such as Portugal, Alves et al 2015). These tend to be much more vocational in nature with low levels of research, and with a greater focus on the local labour market. In the UK though, the experiment with polytechnics in the 1960s and 1970s was mainly focused in the urban areas and since the move to a unitary university system both 'old' and 'new' (former polytechnic) universities have made a move into rural and peripheral areas. One alternative approach though has been the Seinajoki 'university filial centre' in Finland in which several universities collaborate in a locally-focused research facility located in a rural area (Kosonen, 2005).

There has been limited assessment of the economic impact of branch campuses in rural areas. Some attempts have been developed to draw up frameworks for their assessment (Keane and Allison, 1999) and there are anecdotal accounts such as a recent article on the role of a branch campus in the revitalisation of Hastings in East Sussex for example (Else, 2014). An economic impact study was undertaken of the University of the Highlands and Islands (BiGGAR Economics, 2011), but this primarily focused on the production of an estimate of the impact on gross value added (GVA), and 
the contribution to local innovation was given an assumed impact on jobs rather than investigated in any detail. So detailed consideration of the effect on local innovation systems is scarce.

The contribution of branch campuses in particular to regional innovation will depend in part on the research intensity of the campus and the quality of research produced by academic staff. There is concern that branch campuses may generally be regarded as less desirable locations for ambitious academics and therefore will struggle to attract the best researchers. In the US a study of a rural branch campus found a high quality, and intensity of teaching, but a conservative and provincial culture. The small size of the campus led to staff experiencing a greater job complexity, generalism, professional isolation and limited collegiality, all of which mitigated against a more concentrated research focus, and made the campus less attractive for ambitious researchers (Wolfe and Strange, 2003).

Conventionally in the regional development literature we tend to think of a university as a kind of fixed institution, a resource available from a single location, and which is slow to change and adapt to the external world. The university is a source of knowledge and skilled people but its capacity for strategy is assumed to be limited. The main exception is the idea of the entrepreneurial university (Clark, 1998) and the triple helix (Etzkowitz \& Leydesdorff, 1997), but there the focus of action is commercialisation of knowledge, with less of an emphasis on the wider geographical strategy of the institution.

By way of a contrast, the focus in this paper is on the university itself as an actor within a particular geographical context, or even in several different (sometimes radically different) environments. Furthermore, the strategy of the university is an outcome of many different internal actors, each with their own objectives, networks and geographical contexts, at times engaged in a struggle between different strategies and also affected by the strategies, expectations, restrictions and incentives from external partners (Benneworth et al, forthcoming). So rather than seeing a university as a relatively fixed and passive institution, it can at times be engaged in a significant strategic change, including in its geographical form.

A case in point is the decision to establish or maintain a branch or satellite campus, to meet internal or external objectives and targets, and involving negotiation with a variety of external stakeholders as well as those within the institution. Thus a university at one time may be pushed by external bodies to address rural issues, responding to particular incentives or opportunities and with the support of particular groups or visions within the institution. At another time with a different set of external forces, and a change in the internal balance of power, the university may be more driven by financial pressures and external rankings, within which rural and branch campuses are seen as less efficient and making a lower contribution to the university mission. Are branch campuses about the extension of revenue generation or about equity services to the community? The answer varies over time, as well as among groups within $\mathrm{HE}$ and $\mathrm{HE}$ policymakers, and the incentives for each also vary over time and between places.

\section{Rural universities in the UK}

In the UK, as in most other countries, universities are primarily urban institutions. The need to bring together significant numbers of students and academic staff usually requires the externalities found in urban areas, whether it be the provision of rented accommodations, access to transport nodes or 
the simple levels of demand for education from a large population. Yet in more recent years some $\mathrm{HE}$ provision has developed outside of the main urban areas.

Early development of universities in the UK was not urban focused. In England only Oxford and Cambridge existed prior to the 19th century, both relatively small cities in rural areas. In Scotland Edinburgh was the fourth university to be established. The first, St Andrews, was a small town then and still is, whilst even Glasgow was a relatively small town for the first couple of hundred years of the university's existence. The bigger English cities such as London, York, Bristol, Norwich and Newcastle all lacked universities. The 19th century and early 20th century was the time for city universities though. London and each of the large provincial cities established new universities Manchester, Liverpool, Leeds, Sheffield and so on.

The expansion of UK higher education in the 1960s, following a government report by Lord Robbins (1963), changed the trend again. Whilst new technological universities filled in some of the gaps in the cities - Bradford for example - many of the new universities were located in smaller county towns - Guildford, Lancaster, York, Colchester, Canterbury. Although smaller settlements and in more rural areas, these were never seen as rural universities. They were national research universities, recruiting students nationally and not overly focused on local needs. Indeed they were much less local then the civic universities had been in their early days when they were funded by locally-based industrial interests rather than national government. The new polytechnics, established from the late 1960 s onwards, were also mainly based in urban areas.

So prior to the great expansion of HE in the 1990s, rural HE provision was limited. There were a few specialist colleges, often agriculturally focused, some vocational colleges meeting rural needs for teachers and nurses plus perhaps the smaller of the 1960s foundations albeit not rurally focused. 1990s expansion of the HE sector stimulated demand from rural areas, and especially from aspirant county towns, encouraged by the upgrading of colleges in rural areas, and the acquisition of smaller rural institutions by urban universities. As a result a number of rural areas either successfully lobbied for a university campus or suddenly acquired one through the upgrading of their local college. The case studies that follow all emerged as universities or university campuses during this period of expansion.

\section{Method and case studies}

A case study approach was selected for this study as it was of an exploratory nature and the number of available cases in the UK were relatively limited. The aim was to build an understanding of how these small rural campuses engaged with their regions, and so the study was inductive in nature, seeking to assemble new insights that could be used to develop a broader conceptual understanding of the rural campus. As will be seen below, the case studies were quite diverse in nature, and a characteristic of such campuses is their diversity, so case studies were selected to explore this diversity. Six case studies were selected of university campuses in relatively rural areas: three in Scotland and three in Northern England (table 1). In part the case studies were selected for ease of access, but also comprised the main examples of such rural campuses within their respective regions. The selection of cases in England as well as Scotland was necessary in order to reach six cases and provide a variety of experiences, but also enabled some comparison between the different policy environments of Scotland and England as higher education is a devolved topic in the UK. 
In Scotland the three case studies cover the main rural areas outside of the central urbanised belt. In the North the University of the Highlands and Islands (UHI) operates a decentralised model with campuses distributed across the Highlands and Islands from Argyll in the South to Shetland and the Western Isles. The university was established as a joint venture between a network of local further education colleges, and remains a federal system, with the university being jointly owned by the colleges which remain independent of each other (Hills and Lingard, 2003). The university provision remains quite small and students studying on the various campuses draw on a high level of ICTenabled provision. To the South west of the urban central belt of Scotland the Crichton Campus of the small town of Dumfries hosts satellite campuses for both the University of Glasgow and the University of Western Scotland. Here both institutions were induced to set up small campuses around 1999 on the site of a closed mental hospital. The hospital itself had been the result of an endowment in the $19^{\text {th }}$ century following a failed attempt to set up a university there, so there has been a long history of a desire for HE in the town. In the eastern borders the former Scottish College of Textiles in Galashiels became a campus of Heriot-Watt University in Edinburgh following a merger of around 2000 . The college had originally been established in the $19^{\text {th }}$ century by local textile industry interests.

In the English North West, the University of Cumbria was established from a merger of institutions and previous satellite campuses. Like the UHI it operates a series of small campuses across the county of Cumbria and beyond, although all now under a single organisation. In Yorkshire, the University of Hull took over what had been a teacher training college in the coastal resort of Scarborough and turned it into a branch campus with a limited range of courses and around 2000 students. To the south the University of Humberside had established a campus in Lincoln into which it then moved all of its provision, adopting the new name of the University of Lincoln, and closing down campuses in Hull and Grimsby. Subsequently it opened a small specialist food industry campus in South Lincolnshire.

The case studies represent a variety of parent universities also: Glasgow is a Russell Group university, one of the oldest in the UK; Hull and Heriot-Watt are both research intensive also, whilst West of Scotland and Lincoln were polytechnics; and Cumbria and UHI are completely new foundations.

In each case, interviews were held in early 2014. In each of the university campuses an interview was held with a senior manager responsible for the campus (head of campus or main department on the campus) or in the case of whole universities with the senior manager responsible for engagement with business. Additional interviews were held with other enterprise engagement or departmental staff in the campus. Altogether 14 staff were interviewed across seven universities as there were two universities present on the Dumfries campus. Also in each case representatives of external stakeholders in local authorities, enterprise agencies or chambers of commerce were interviewed. A total of 15 external stakeholders were interviewed. Most interviews lasted around an hour although some were substantially longer. Interviews were recorded and transcribed, and were supported by a review of various institutional annual reports and strategic plans, plus strategy documents originating from external sources relating to local economic development.

\section{The nature of the regions}


The cases were all chosen to represent regions or sub-regions which are largely rural, although the university is typically based in the largest town, which might be a small city of around 100,000 people or less. The central town or city was in all cases standalone and not part of a larger agglomeration, so the main character was of a rural region with a main service centre. Whilst the character of these regions was predominantly rural with a particular specialisation in agriculture or primary industries, plus usually tourism, the full economic profile of the region was much more complex. Whilst specialisation is expected based on the nature of the land - fishing and sheep farming in the Scottish Islands, arable farming in Lincolnshire - these areas actually had much more diverse economies.

What emerged strongly in all the regions was the strength of manufacturing as a share of employment, with most of the areas showing a level above the national average, and significantly higher than the big metropolitan core cities which are now specialised on services. This was reflected in the nature of the demands made by local employers on the university as interpreted by regional agencies and local authorities. Manufacturing industry was seen as important even if largely comprising SMEs and also relatively diverse, although there were a few large industrial employers in some of the cases.

In the Scottish cases, both of the border regions had a significantly higher level of manufacturing employment than the Scottish average - in the case of Borders region, with a long heritage of textiles, whilst Dumfries and Galloway has a diverse industrial base including food, forestry and engineering. The Highlands and Islands region was more diverse with one district, Moray, with a very high manufacturing employment linked in part to the offshore fabrication sector whilst others were near or less than the national average. All were more manufacturing intensive than Edinburgh though and all except Argyll and Bute had a high proportion of manufacturing workers than Glasgow.

In Cumbria, all except one district were above the national average for manufacturing employment, in some cases massively over as in Copeland (focused on the Sellafield nuclear reprocessing plant) and Barrow (building submarines). Scarborough district and its neighbouring Ryedale also had above average manufacturing employment although less than Hull where the parent university was based. Lincoln was around the national average, but the surrounding districts, largely rural, had higher levels of manufacturing employment.

All the regions had medium to low levels of GDP, relatively poor levels of skills and innovation

What this illustrates is that the nature of the local demands on these rural campuses is likely to be mixed, not just focused on agriculture, tourism and local services, but including a diverse set of manufacturing industries, including some very large and sophisticated businesses but mainly SME based.

\section{Scale and specialisation of the campus}

Most of the campuses in the study inevitably were quite small in scale, typically less than 2000 students, usually completely or predominantly undergraduates, and this is normal for branch campuses in rural areas in other countries also. The mix of students varied, in terms of part-time and full-time and young adult or mature, depending on the strategy of the campus. Lincoln was the 
exception as a full range university of over 13,000 students on a single campus in the centre of a small city, and as such its primary reason for inclusion in the study was as an exemplar of what the other towns and cities in the study would perhaps aspire to. In Lincoln's case at an early stage the university shifted strategy from the establishment of a branch campus to making that campus the main site of the university - an outcome which was never likely at any of the other sites. Although Cumbria and University of the Highlands and Islands (UHI) are also universities in their own right, they have been unable to achieve a similar scale and concentration in a single place due to the strong political pressure for a network of campuses across a broader rural area, coupled with their relatively small overall size. Both are smaller overall than Lincoln but operating across multiple campuses.

The comparison between Lincoln and the others in terms of scale and the implications of specialisation is instructive. Scale allows a university to develop a wide range of offerings - being comprehensive but achieving specialisation across a range a disciplines. Hence, for example, Lincoln has been able to establish a new school of engineering. 13,000 is perhaps at the low end for a comprehensive university, and Lincoln is still perhaps more specialised than other universities, as the economics of higher education push for greater scale. Back in the 1970s and 1980s a comprehensive UK research university (including some of those now in the Russell Group) could offer a full range of disciplines, including medicine and engineering, with less than 8,000 students, whereas now a similar range would require nearer 20,000. Thus small campuses with 2000 students have to be highly specialised to meet the demands of scale economies, and even then the economics are fragile.

The main dilemma for the small branch campus is the choice between meeting the educational need of the local community - specialising in teaching across a range of usually vocational disciplines - or focusing on smaller number of disciplines where both research and teaching can be linked to the local region. In the first approach the campus has a primary aim of addressing issues of equity and access, usually picking a range of popular courses, often vocational, and offering parallel provision to that on the main campus. Local staff will therefore work with colleagues on the main or other campuses to deliver teaching programmes, and the campus is likely to lack a strong research culture. In the case of a research-based university this may be a point of tension within the wider university strategy. Typical disciplines would include teaching, nursing, management and various social science and humanities. STEM subjects are usually difficult to offer in this context because of the capital investment required for lab facilities.

At the other extreme is the small campus specialised on perhaps one or two disciplines or themes, where whole schools or research centres are based on the campus, and the staff there are expected to meet university norms of research intensity. This is the case for example of the Heriot-Watt campus at Galashiels, which only consists of the School of Textiles and Fashion.

In reality most of the branch campuses try to achieve some form of hybrid between the two, combining some specialist research-driven provision, with some mainstream courses which duplicate the offer of the main campus. The UHI has sought to make a virtue of this by offering core degrees across all campuses using a high level of ICT provision, whilst also encouraging unique specialisations on each campus based on local expertise and contexts. Dumfries was interesting in that the campus had two universities present, each with a different strategy - Glasgow had a 
specialist offering on the campus and constituted a single school in the faculty of Social Sciences, whilst the University of the West of Scotland delivered degrees from several schools on the site.

The nature of the choices for specialisation has significant impacts on the links with the local community. A university following an equity approach will largely teach local students, perhaps mostly living at home, with the expectation that most will later seek work in that local community. There may be good local links with employers, but this will be focused around the degrees offered, often public sector oriented such as teaching. A campus that is specialised on particular disciplines with a research focus, is more likely to recruit from outside the region, with students living in university accommodation and having a bigger short-term impact as they are net additions to the local population, requiring accommodation, nightlife and adding diversity to the local population. The research focus of such campuses creates opportunities to collaborate with a subset of local firms in a deeper way, especially if the specialisation was chosen particularly for such reasons, but may have little to offer the wider base of local industry.

In most cases the universities had chosen to develop specialisations that had some relevance for the local area. In Galashiels this arose from the origins of the campus in the local textiles industry, but in all the other cases this specialisation was more recent. One respondent explained that being a relatively new institution there was little point competing for mainstream research council funds, but that by aiming at local interests there was funding from regional agencies, firms and EU regional funds to build up research capacity. Typically though this was in specialised interdisciplinary areas and might not fit well with the teaching demand from students. All but one of the institutions identified specific areas of research and engagement specialisation. Examples of more significant collaboration with larger locally based companies included a partnership focused on diabetes research between UHI, the National Health Service and LifeScan (a Johnson and Johnson company which employs 1000 people in Inverness), and the development of an engineering school by the University of Lincoln with the close collaboration of a local division of Siemens.

\section{Community expectations}

The nature of the scale and specialisation of the campuses were found to affect the view of regional partners relative to their initial expectations. As most of these campuses were new, or newly raised to university status, there were expectations in the local community of the benefits that could be realised by having a local university, but these were usually based on experiences of full universities based in more urban regions rather than the limitations of a small branch campus or a new distributed university in a rural region.

In most of the interviews with local stakeholders there was some expression of disappointment that the university campus had not as yet fully met the expectations of the local community. In a couple of cases this related to the sense of vitality of the urban centre, that what had been expected was that the coming of the university would contribute to a livelier and more cosmopolitan community there may have been some progress on this but not as much as had been anticipated. This reflects the small scale of the campus, and the balance of local to non-local students. This view was not shared everywhere however and some of the campuses were seen as important sources of revenue for local businesses through the attraction of students into the locality as well as related visitors in the form of students' families at graduation, and attendees at conferences organised by the university. The nature of the impact depended a little on whether the students were living in campus 
accommodation, or in accommodation in the town itself, the latter case offering the opportunity for regeneration of town centre areas. Lincoln was the notable exception, where the development of a full-range university had had a transformational effect on the city, and provided an example of what the communities elsewhere had been hoping to see.

\begin{abstract}
A bigger criticism related to the nature of support for local industry. Here the main concern in several of the locations with smaller campuses was that the university did not yet have the expertise needed by local businesses, either in sectoral terms or in terms of the quality of support. Whilst the campus might have an area of specialisation with local partners, there were other local manufacturing firms whose needs were not being met by the campus, especially in areas of science and engineering. Stakeholders typically felt divided loyalties in that they wanted to help the development of the campus and were committed to working with the campus and extending its capabilities, but recognised that its ability to support local business was limited. In several cases, stakeholders also worked with external universities in parallel as they had greater expertise in particular fields and in the delivery of programmes that were in demand in the region. Business support agencies were referring firms to universities outside of the region, and asking universities from other regions to deliver training courses for local businesses.
\end{abstract}

\title{
Support for business innovation
}

The mismatch between the programmes and research capacities of the university campuses and the needs of local industry has inevitably hindered the development of local linkages. Obviously where specialist provision and research capabilities coincided with local industries there has been a greater opportunity for interaction, but these have tended to be the limited in scope.

As already noted, the needs of local business in these rural regions were more complex than might be initially imagined as the economic base included a significant, and often quite varied, level of manufacturing industry, in addition to more traditional rural sectors related to agriculture and tourism. Whilst some of this manufacturing included food processing (eg in Lincolnshire and Dumfries and Galloway), there were also significant engineering businesses in Scarborough, Lincoln, Moray (Highlands), and Cumbria, textiles and clothing (Borders) and the specific case of the nuclear industry in Caithness and West Cumbria. Some of these industrial sectors had quite specific innovation support needs, and in the case of larger enterprises, in the nuclear industry for example, were linked to national university networks. A more pertinent challenge was support for local SMEs with interests in innovation.

Agencies in the regions reported two main avenues for innovation support for SMEs. Several of the regions had or were developing programmes to work with local SMEs, with an aim to raise their innovative capacities or competitiveness. Whilst there was a desire to involve the local HEls in these programmes, there was also a concern that the local campuses did not have all the expertise needed, and in some cases a concern over the quality of expertise. So agencies still looked to larger universities based outside the region as partners in these programmes, particularly addressing the higher level skills and expertise, whilst the local campus was seen as adequate for more routine support, such as enterprise training for young people. In one case, local entrepreneurs were sent away to a leading university for high level development courses, even though the local campus claimed to offer entrepreneurship and management training. 
The other form of support was in response to particular requirements, often identified by field staff from various agencies. The local university campuses had limited resources of their own to go seeking out SME demands, although one campus employed a former industrial manager to maintain links with key firms in their target industry sectors. Some of these links were said to be close and long lasting, and whilst local agencies had little awareness of these links this may be down to those firms not needing to approach the agencies in addition to the university. Generally where agencies worked with SMEs, the needs they identified were rarely capable of being met by the local university campus. Examples were given of local SMEs that had developed links with universities, but where it was with larger universities based outside the immediate region in more urban areas.

From the university perspective, there were many examples of specialist research groups that were developing local linkages: sometimes with industry groups but also with public sector interests in environmental issues for example. These were seen as successful examples of engagement, although the emphasis tended to be on supporting existing industry through path extension, and it was generally the more traditional rural industries around resources and tourism that were the focus of development. In the absence of the scale economies and sunk investment required for major science and engineering research the potential for path creation, or even for support for larger engineering businesses was highly limited.

\section{Campus viability}

Given some of the challenges faced by the campuses, the difficulties in meeting local expectations, and the challenges created by the wider HE system, some of the campuses have experienced difficulties even leading to threats of closure. Indeed just after the round of interviews for this study was concluded, Hull University announced its intention to cease recruitment of students to its Scarborough campus with the aim of closure in three years. Subsequently it has been decided to transfer the campus to Hull College with the University of Hull retaining a presence in the short term, although withdrawing from degree provision. Subsequently Coventry University has announced its intention to open a new campus in Scarborough.

Previous threats of closure had been made at Glasgow's Dumfries campus, Heriot-Watt's Galashiels campus and actual closures were made at some Cumbria campuses. In each case there has been local resistance to closure, with the result that campuses have been saved. Lincoln closed down its urban campus in relocating to Lincoln as well as a satellite campus in Grimsby, and only UHI has so far avoided this issue, mainly because its constituent colleges are committed to operating in their respective sub-regions, and are self-sufficient entities based on their vocational training programmes.

\section{Conclusions}

Although rural university campuses have been politically popular at a local level and encouraged at times by governments at a national scale in the UK and elsewhere, the evidence of their benefits is at best mixed. Educationally there may be benefits for some students, particularly mature students with family commitments, to being able to study locally, although these opportunities are often limited in terms of discipline and types of programme. If a campus alternatively attracts students from outside of the area then there is also a potential benefit from the influx of young people, often increasing local diversity, and invigorating the local economy at least in the centre of the town 
where the campus is based. The presumptions of a wider benefit in terms of knowledge spillovers to local industry and local innovation is however much more difficult to achieve. The challenges of a lack of scale and a need to specialise both mitigate against significant engagement with local industry.

So whilst these new campuses have been able to add to the regional innovation systems of these rural areas, to some degree, they struggle with economies of scale and scope, especially facing the reality of rural business which is not always the mix of agriculture and tourism that is the stereotype. Where specialisation has been the strategy, potential exists for niche clusters to develop, although in most cases the campus requires a longer development period to reach its full potential. The limited scale of resources restricts the potential for significant spin off development, but several of the campuses are starting to promote graduate entrepreneurship. Rural regions seeking to attract a university campus should consider whether there are specific areas of specialisation they would wish to encourage and ascertain how these would fit with the portfolio of any university they were seeking to attract. It is not clear how it is possible to guarantee a long term commitment from a university to provide a particular form of research and teaching on a rural campus, especially within a neo-liberal system such as the UK. However, some form of shared investment might help to ensure an input from local agencies in the development of the campus. A commitment to giving a campus an exclusive role within the university for a particular discipline area would help to prevent internal competition between sites for key staff and students.

Where a rural area sees their primary need as being a campus to encourage greater participation in $\mathrm{HE}$ and the provision of a range of degrees for local students then it needs to be acknowledged at the outset that the potential for industry engagement is likely to be limited unless the scale of campus is relatively large. Here again long term commitment to the site will need to be reinforced through political pressure, especially as the likely cost to the university of withdrawal may not be significant. Again some local part ownership of the campus may help by bringing in another university to run the campus if the initial university decides to withdraw. Overall though policies to enhance rural innovation through new university campuses must be seen to be very long term strategies and not necessarily congruent with strategies to increase HE participation and retain young people through local degree provision. 


\section{Funding}

This work was supported by an internal grant from the University of Strathclyde

\section{Acknowledgements}

The author wishes to thank Stephen Miller at the University of Strathclyde for his support in organising the interviews for this project. Thanks are also due to attendees at the Social Dynamics of Innovation Networks conference in Heerlen, the EU-SPRI conference on Science and Innovation Policy in Manchester, and the Regional Innovation Policies conference in Stavanger, all in 2014, for the helpful comments made on earlier drafts of this paper. Very helpful comments on an earlier draft of the paper were also made by Romulo Pinheiro. Finally, thanks are also due to the editors of this special issue and two anonymous reviewers whose additional thoughts and suggestions were extremely helpful, and greatly appreciated.

\section{References}

Allison, J and R Eversole 2008. A new direction for regional university campuses: catalysing innovation in place Innovation: The European Journal of Social Science Research, 21(2), XXXX.

Arbo, $\mathrm{P}$ and $\mathrm{H}$ Eskelinen 2003. The Role of Small, Comprehensive Universities in Regional Economic Development: Experiences from Two Nordic Case. Paper for the 43rd ERSA Congress, Jyväskylä, Finland, 27-30 August, 27-30 August. Online at: https://www.jyu.fi/ersa2003/cdrom/papers/530.pdf Atterton, J and N Thompson 2010. University engagement in rural development: a case study of the Northern Rural Network, Journal of Rural and Community Development, 5, 123-132.

Bender, T. 1991. The University and the City: from Medieval Origins to the Present. Oxford: Oxford University Press

Benneworth, P 2013. University Engagement with Socially Excluded Communities, Dordrecht: Springer.

Benneworth, P., R. Pinheiro, and J. Karlsten. Forthcoming.

https://www.academia.edu/11433398/Strategic_Agency_and_Institutional_Change_Investigating_t he_Role_of_Universities_in_Regional_Innovation_Systems_RISs_

BiGGAR Economics (2011) Economic Impact of the UHI Millennium Institute and its Academic Partners, report to the UHI Millennium Institute. Roslin, Midlothian BiGGAR Economics.

Charles, D (2006) 'Universities as key knowledge infrastructures in regional innovation systems', Innovation: The European Journal of Social Science Research, 19, 117-130. 
Charles, D. R. (2009) 'Developing universities and research potential in peripheral regions', Regions, the Newsletter of the Regional Studies Association, 273, 6-9.

Charles, D, S Bowman, S Garlick, and L Tait 2006. Supporting the Contribution of Higher Education Institutions to Regional Development, Peer Review Report: Sunshine-Fraser Coast, Australia. Paris: OECD.

Chatterton, $\mathrm{P}$ and $\mathrm{J}$ Goddard, 2000. The response of higher education institutions to regional needs. European Journal of Education, 35, 475-496.

Clark, B R 1998. Creating Entrepreneurial Universities: Organizational Pathways of Transformation. Oxford: International Association of Universities and Elsevier Science Ltd.

Department for Innovation Universities and Skills (UK) 2008 A New University Challenge: Unlocking Britain's Talent. London: HMSO.

Dudley, J and K Longley, 2004. The new front door: The changing role of regional campuses, in University Regional and Rural Engagement, AUCEA Refereed Conference Proceedings 2004, Australian Universities Community Engagement Alliance, Office of Regional Development, University of Western Sydney.

Else, $\mathrm{H}$ 2014. Education with an eye to regeneration, Times Higher Education, issue $2141,27^{\text {th }}$ February, 20-21.

Etzkowitz, H and L Leydesdorff, 1997. Universities and the Global Knowledge Economy: A Triple Helix of University-industry-government Relations. London: Pinter.

Garlick, S 1998. Creative Associations in Special Places: Enhancing the partnership role of universities in building competitive regional economies, Southern Cross Regional Research Institute, Southern Cross University, report for the Evaluation and Investigations Programme of the Department of Employment, Education, Training and Youth Affairs. Canberra: Commonwealth of Australia

Goddard, J and P Vallance 2013. The University and the City. Abingdon: Routledge.

Gunasekara, C 2006. The generative and developmental roles of universities in regional innovation systems. Science and Public Policy, 33: 137-150.

Hills, G and R Lingard 2003. UHI: the Making of a University. Edinburgh: Dunedin Academic Press.

Isaksen, A and M Trippl 2014. Regional industrial path development in different regional innovation systems: A conceptual analysis, CIRCLE Papers in Innovation Studies, Paper no. 2014/17, University of Lund.

Karlsen, $\mathrm{J}$ 2005. When regional development becomes an institutional responsibility for universities: The need for a discussion about knowledge construction in relation to universities' third role. Al \& Society, 19, 500-510.

Keane, J and J Allison 1999. The intersection of the learning region and local and regional economic development: analysing the role of higher education, Regional Studies 33: 896-902. 
Kosonen, K-J 2005. Strengthening the Research and Educational Basis for Regional Development in Less-Favored Regions, MIT IPC Local Innovation Systems Working Paper 05-003. Cambridge MA: MIT.

OECD 2007. Higher Education and Regions: Globally Competitive, Locally Engaged. Paris: OECD.

Patton, D and M Kenney 2010. The role of the university in the genesis and evolution of researchbased clusters, in Fornahl, D., Henn, S. and Menzel, M.-P. (eds) Emerging Clusters: Theoretical, Empirical and Political Perspectives on the Initial Stage of Cluster Evolution, Edward Elgar, Cheltenham, UK, 214-238.

Pinheiro, R. 2014. Regional policy and higher education: the case of Northern Norway In Higher Education and Research in Academe - Who should pay?, edited by T. Aarevaara and E. Berg, 53-64. Luleå: Luleå Tekniska Universitet.

Pinheiro, R., Charles, D. and Jones, G.A. 2016,forthcoming. Equity, institutional diversity and regional development: a cross country comparison, $\underline{\text { Higher Education }}$

Robbins, C B 1963. Higher Education: Report of the Committee Appointed by the Prime Minister under the Chairmanship of Lord Robbins, London: Her Majesty's Stationery Office

Schuman, S 2009. Leading America's Branch Campuses, Rowman \& Littlefield Education

Siegel, D S, M Wright, and A Lockett, 2007. The rise of entrepreneurial activity at universities: Organizational and societal implications, Industrial and Corporate Change, 16, 489-504.

UNICREDS 2012. University partnerships for Prosperity: How Higher Education can help build Regional Knowledge Based Economies in Europe, Final report of learning and outcomes from the UNICREDSS project, http://www.unicreds.eu/documents/doc_download/unicreds-final-reportweb.pdf

Uyarra, E, 2010. Conceptualizing the regional roles of universities, implications and contradictions. European Planning Studies, 18: 1227-1246.

Ward, N, J Atterton, T-Y Kim, P Lowe, J Phillipson and N Thompson, 2005. Universities, the knowledge economy and 'neo-endogenous rural development', Centre for Rural Economy Discussion paper series No 1. Newcastle upon Tyne: Newcastle University.

Willetts, D 2014. New higher education campuses, letter from the UK Minister for Universities and Science to the Chief Executive of the Higher Education Funding Council for England, $3^{\text {rd }}$ April. London: Department of Business Innovation and Skills.

Wise, G 2016. How regional universities drive regional innovation, Australian Government, Department of Industry, Innovation and Science, Canberra.

Witty, A. 2013. Encouraging a British Invention Revolution: Sir Andrew Witty's Review of Universities and Growth, HMSO, London.

Wolfe, J R and C C Strange 2003. Academic life at the franchise: faculty culture in a rural two-year branch campus, The Review of Higher Education, 26, 343-362. 
Youtie, J and P Shapira 2008. Building an innovation hub: A case study of the transformation of university roles in regional technological and economic development, Research Policy, 37, 1188$\underline{1204 .}$ 


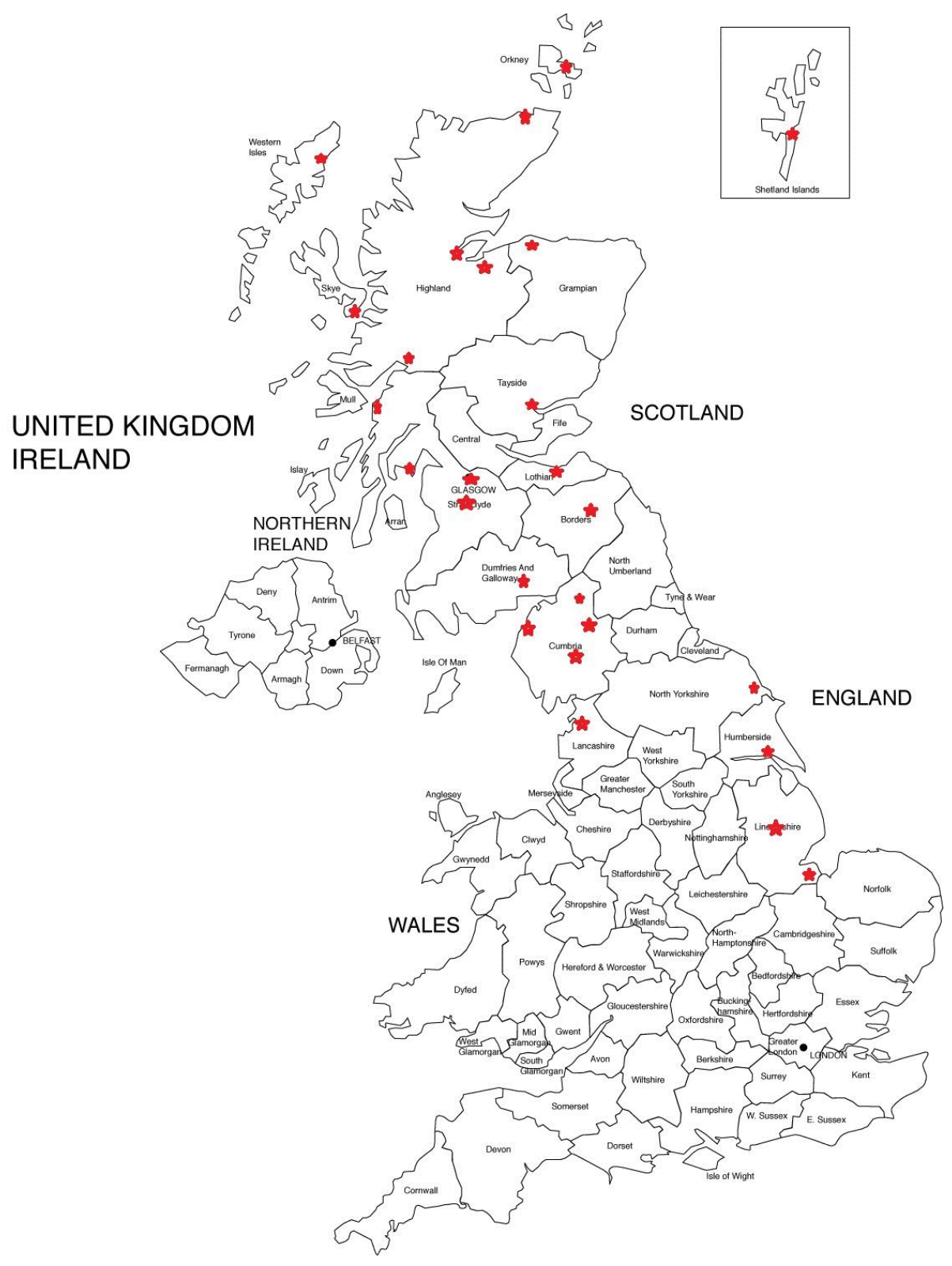


Table 1: The universities and campuses

\begin{tabular}{|c|c|c|c|c|c|}
\hline Location & University & Origins & Form & Scale & Regional context \\
\hline $\begin{array}{l}\text { Inverness - } \\
\text { Highlands and } \\
\text { Islands of Scotland }\end{array}$ & $\begin{array}{l}\text { University of the } \\
\text { Highlands and } \\
\text { Islands }\end{array}$ & $\begin{array}{l}\text { New development from } \\
\text { the } 1990 \text { s built on a } \\
\text { network of } 12 \text { existing } \\
\text { vocational colleges and } \\
\text { one environmental } \\
\text { research institute across } \\
\text { the region }\end{array}$ & $\begin{array}{l}\text { The University is } \\
\text { headquartered in Inverness } \\
\text { where one of the partners is } \\
\text { based. Each of the partners } \\
\text { is a free standing institution } \\
\text { which undertakes higher } \\
\text { education activity on behalf } \\
\text { of the university. }\end{array}$ & $\begin{array}{l}\text { The University has } \\
\text { a total of 5-6000 } \\
\text { higher education } \\
\text { students across its } \\
\text { campuses, } \\
\text { although with a } \\
\text { much higher } \\
\text { number of } \\
\text { vocational } \\
\text { education students } \\
\text { in the constituent } \\
\text { colleges }\end{array}$ & $\begin{array}{l}\text { The Highlands and } \\
\text { Islands region is an } \\
\text { extremely sparsely } \\
\text { populated region in } \\
\text { the North of the } \\
\text { UK. Although } \\
\text { traditionally } \\
\text { dominated by rural } \\
\text { industries, the area } \\
\text { does have some } \\
\text { centres of industry } \\
\text { such as in support } \\
\text { of the oil and gas } \\
\text { sector. Some of the } \\
\text { islands have a } \\
\text { distinct Gaelic } \\
\text { language and } \\
\text { culture. }\end{array}$ \\
\hline \multirow[t]{2}{*}{$\begin{array}{l}\text { Dumfries, Dumfries } \\
\text { and Galloway, } \\
\text { Scotland }\end{array}$} & $\begin{array}{l}\text { University of } \\
\text { Glasgow }\end{array}$ & $\begin{array}{l}\text { Newly established on } \\
\text { the site of a redundant } \\
\text { hospital campus }\end{array}$ & $\begin{array}{l}\text { Glasgow is an ancient } \\
\text { research intensive civic } \\
\text { university based in central } \\
\text { Glasgow. The Dumfries } \\
\text { campus constitutes a single } \\
\text { school in the social sciences } \\
\text { faculty. }\end{array}$ & $\begin{array}{l}300 \text { students in } \\
\text { Dumfries out of } \\
23,000 \text { in the } \\
\text { university as a } \\
\text { whole }\end{array}$ & \multirow{2}{*}{$\begin{array}{l}\text { Dumfries and } \\
\text { Galloway is a rural } \\
\text { region on the } \\
\text { border with } \\
\text { England. Dumfries } \\
\text { is the main centre } \\
\text { in the region but } \\
\text { has a population of } \\
\text { less than 50,000. }\end{array}$} \\
\hline & $\begin{array}{l}\text { University of the } \\
\text { West of Scotland }\end{array}$ & $\begin{array}{l}\text { Newly established on } \\
\text { the site of a redundant } \\
\text { hospital campus }\end{array}$ & $\begin{array}{l}\text { UWS was previously a } \\
\text { Scottish equivalent of a } \\
\text { polytechnic, based in Paisley, }\end{array}$ & $\begin{array}{l}\text { c500 students out } \\
\text { of } 20,000 \text { in the } \\
\text { university as a }\end{array}$ & \\
\hline
\end{tabular}




\begin{tabular}{|c|c|c|c|c|c|}
\hline & & & $\begin{array}{l}\text { and is hence more teaching } \\
\text { focused. Several schools } \\
\text { within the university deliver } \\
\text { programmes in Dumfries } \\
\text { with some staff travelling } \\
\text { from other campuses to } \\
\text { teach. }\end{array}$ & whole. & \\
\hline $\begin{array}{l}\text { Galashiels, Borders } \\
\text { Region, Scotland }\end{array}$ & $\begin{array}{l}\text { Heriot-Watt } \\
\text { University }\end{array}$ & $\begin{array}{l}\text { The campus was } \\
\text { originally a College of } \\
\text { textiles established in } \\
\text { the } 19^{\text {th }} \text { century to } \\
\text { support local industry, } \\
\text { which was merged with } \\
\text { Heriot-Watt in } 1998 \text {. }\end{array}$ & $\begin{array}{l}\text { The campus consists of a } \\
\text { single complete school, one } \\
\text { of eight in the University. }\end{array}$ & $\begin{array}{l}550 \text { students on } \\
\text { campus compared } \\
\text { with } 11,000 \text { on the } \\
\text { main Edinburgh } \\
\text { campus }\end{array}$ & $\begin{array}{l}\text { Borders region is } \\
\text { another rural } \\
\text { region on the } \\
\text { border with } \\
\text { England. The area } \\
\text { has a strong } \\
\text { manufacturing } \\
\text { tradition mainly in } \\
\text { textiles, but has } \\
\text { seen considerable } \\
\text { decline in recent } \\
\text { decades. Galashiels } \\
\text { is the largest town, } \\
\text { with a population } \\
\text { of } 15,000 \text {. }\end{array}$ \\
\hline Carlisle, Cumbria & $\begin{array}{l}\text { University of } \\
\text { Cumbria }\end{array}$ & $\begin{array}{l}\text { The University was } \\
\text { formed in } 2007 \\
\text { through the } \\
\text { amalgamation of local } \\
\text { colleges and campuses } \\
\text { that were formerly } \\
\text { branches of other } \\
\text { universities. }\end{array}$ & $\begin{array}{l}\text { The University is } \\
\text { headquartered in Carlisle } \\
\text { and has additional campuses } \\
\text { elsewhere in Cumbria as well } \\
\text { as in Lancaster }\end{array}$ & $\begin{array}{l}\text { Around } 9000 \\
\text { students across } 6 \\
\text { campuses. }\end{array}$ & $\begin{array}{l}\text { Cumbria is a rural } \\
\text { county on the } \\
\text { border with } \\
\text { Scotland, much of } \\
\text { which consists of } \\
\text { the Lake District } \\
\text { national park. } \\
\text { Despite a base of } \\
\text { tourism and } \\
\text { agriculture the } \\
\text { county has a high }\end{array}$ \\
\hline
\end{tabular}




\begin{tabular}{|c|c|c|c|c|c|}
\hline & & & & & $\begin{array}{l}\text { level of } \\
\text { manufacturing. }\end{array}$ \\
\hline Lincoln & University of Lincoln & $\begin{array}{l}\text { Originally the University } \\
\text { of Humberside based in } \\
\text { Hull, the University } \\
\text { established a new } \\
\text { campus in Lincoln in } \\
1996 \text { and eventually } \\
\text { moved all its activities } \\
\text { to Lincoln, renaming the } \\
\text { institution }\end{array}$ & $\begin{array}{l}\text { The University is essentially a } \\
\text { single campus in the centre } \\
\text { of Lincoln, but with a small } \\
\text { presence also on the } \\
\text { northern edge of Lincoln, } \\
\text { and a small food technology } \\
\text { campus at Holbeach in South } \\
\text { Lincolnshire }\end{array}$ & $\begin{array}{l}13,000 \text { students } \\
\text { almost all based in } \\
\text { Lincoln. }\end{array}$ & $\begin{array}{l}\text { Lincolnshire is a } \\
\text { large rural county } \\
\text { on the East coast of } \\
\text { England, known for } \\
\text { its arable farming. } \\
\text { Lincoln is the main } \\
\text { city in the centre of } \\
\text { the county with a } \\
\text { population of } \\
130,000 \text {. }\end{array}$ \\
\hline Scarborough & University of Hull & $\begin{array}{l}\text { The campus was a } \\
\text { former teacher training } \\
\text { college which merged } \\
\text { with the University of } \\
\text { Hull }\end{array}$ & $\begin{array}{l}\text { The campus consisted of } \\
\text { parts of several departments } \\
\text { all managed from Hull. A } \\
\text { head of campus was } \\
\text { appointed to coordinate } \\
\text { local activities. The campus } \\
\text { is currently being transferred } \\
\text { to Hull College. }\end{array}$ & $\begin{array}{l}\text { Around } 1500 \\
\text { students on the } \\
\text { campus out of } \\
17,000 \text { in total. }\end{array}$ & $\begin{array}{l}\text { Scarborough is a } \\
\text { seaside resort in } \\
\text { North Yorkshire, a } \\
\text { rural county } \\
\text { containing two } \\
\text { national parks. } \\
\text { Scarborough has a } \\
\text { population of } \\
60,000 \text {. }\end{array}$ \\
\hline
\end{tabular}

